\title{
Travel-related Zika virus cases in Canada: October 2015-June 2017
}

\author{
J Tataryn ${ }^{1 *}$, L Vrbova², M Drebot ${ }^{3}$, H Wood $^{3}$, E Payne ${ }^{4}$, S Connors², J Geduld ${ }^{4}$, M German ${ }^{5}$, \\ K Khan ${ }^{5,6}$, PA Buck ${ }^{7}$
}

\section{Abstract}

Background: Zika virus (ZIKV) is an emerging mosquito-borne disease that can cause severe birth defects if contracted congenitally. Since late 2015, there has been a large increase in the number of travel-related cases of Zika virus infection in Canada.

Objective: The objective of this study was to describe the epidemiology of travel-related Zika cases in Canada from October 2015 to June 2017 and review them in the context of the international outbreak in the Americas.

Methods: Zika virus infections were confirmed by polymerase chain reaction (PCR) detection of viral RNA and/or the serological identification of ZIKV-specific antibodies in serum. Cases of ZIKV infection were identified by provincial and territorial health authorities, and reported on a regular basis to the Public Health Agency of Canada (PHAC). Case information requested included date of illness onset, age category, sex, pregnancy status, and location(s) and dates of travel. Estimates for the monthly number of Canadians travelling outside of Canada to other countries in the Americas were obtained from Statistics Canada and the International Air Transport Association (IATA). Data to produce the epidemic curves of autochthonous cases for each region of the Americas were extracted from country-specific epidemic curves on the Pan American Health Organization website.

Results: As of June 7, 2017, 513 laboratory confirmed cases and two Zika-related birth/fetal anomalies were reported across all 10 provinces. Illness in Canadian travellers generally coincided with outbreak intensity in the country of exposure rather than travel volume. There has been no evidence of autochthonous (local) transmission in Canada. Currently, cases are on the decline both in Canada and internationally.

Conclusion: The surge in Canadian ZIKV infections in 2016 was directly related to the incursion and spread of ZIKV into the Americas. Although cases are now on the decline worldwide, it remains to be seen whether a resurgence of cases in previously affected or new areas will occur. Both outbreak intensity and seasonality of ZIKV transmission should be monitored over time in order to inform the timing of public health education campaigns, as some may turn out to be more effective in the off-peak travel season when the risk of disease transmission may be higher. Ongoing education and awareness among travellers, particularly for pregnant women and those planning pregnancies, is still indicated.

\section{Affiliations}

${ }^{1}$ Centre for Food-borne, Environmental and Zoonotic Infectious Diseases (CFEZID), Infectious Disease Prevention and Control Branch, Public Health Agency of Canada, Saskatoon, SK

${ }^{2}$ Centre for Food-borne, Environmental and Zoonotic Infectious Diseases (CFEZID), Infectious Disease Prevention and Control Branch, Public Health Agency of Canada, Toronto, ON

${ }^{3}$ National Microbiology Laboratory, Infectious Disease Prevention and Control Branch, Public Health Agency of Canada, Winnipeg, MB

${ }^{4}$ Office of Border and Travel Health, Health Security and Infrastructure Branch, Public Health Agency of Canada, Ottawa, ON

${ }^{5}$ Department of Medicine, Division of Infectious Diseases, University of Toronto, Toronto, ON

${ }^{6}$ Li Ka Shing Knowledge Institute, St. Michael's Hospital, Toronto, ON

${ }^{7}$ Centre for Food-borne, Environmental and Zoonotic Infectious Diseases (CFEZID), Infectious Disease Prevention and Control Branch, Public Health Agency of Canada, Ottawa, ON

${ }^{\star}$ Correspondence: joanne. tataryn@canada.ca

Suggested citation: Tataryn J, Vrbova L, Drebot M, Wood H, Payne E, Connors S, Geduld J, German M, Khan K, Buck PA. Travel-related Zika virus cases in Canada: October 2015-June 2017. Can Commun Dis Rep. 2018;44(1):18-26. https://doi.org/10.14745/ccdr.v44i01a05

\section{Introduction}

Zika virus (ZIKV) is a mosquito-borne flavivirus primarily transmitted to humans by Aedes species mosquitoes. First identified in 1947 in the Zika forest of Uganda (1,2), ZIKV was largely confined for over fifty years to a relatively narrow equatorial belt running from Asia to Africa (3). In 2007, the first major outbreak of ZIKV was reported on the island of Yap (Micronesia) (4), followed by several outbreaks on islands and archipelagos in the Pacific region, including a large outbreak in French Polynesia in 2013 (5,6). Zika virus was first reported in Brazil in 2015 and has since emerged across Central and
South America, the Caribbean and Mexico. Concurrent with this outbreak was an alarming increase in cases of babies with microcephaly and other neurological disorders born to ZIKV-infected mothers. As a result, the World Health Organization (WHO) declared a Public Health Emergency of International Concern (PHEIC) on February 1, 2016, requesting international response and collaboration (7).

Zika virus is predominately spread through the bite of an infected mosquito; however, it can also spread via vertical intrauterine, and sexual and blood-borne transmission routes 
(8-14). Only an estimated $20 \%$ of those infected with ZIKV will develop symptoms (4). If symptoms do occur, they typically develop within three to seven days (maximum 14 days) following infection and include low-grade fever, arthritis/ arthralgia, maculo-papular rash, conjunctivitis, myalgia and other non-specific flu-like symptoms $(4,15)$. Infection may go unrecognized or be misdiagnosed as dengue, chikungunya or other viral infections causing fever and rash. Rarely, neurologic complications such as Guillain-Barré syndrome have been reported (16).

Of greatest concern is the serious effects ZIKV infection can have on a developing fetus, resulting in a spectrum of congenital anomalies known as congenital Zika syndrome (CZS). Brain abnormalities and microcephaly are commonly reported $(17,18)$ but CZS is also known to include arthrogryposis (reduced mobility of multiple joints due to contractures), dysphagia (difficulty swallowing), auditory deficits, visual impairment and other anomalies (19). Reports from the United States Zika Pregnancy Registry found that an estimated 5\% (95\% confidence interval $[\mathrm{Cl}]=4 \%-7 \%$ ) of completed pregnancies with laboratory evidence of possible recent ZIKV infection (i.e., recent flavivirus exposure) had a fetus or infant with evidence of CZS. The proportion increased to $10 \%(95 \% \mathrm{Cl}=7 \%-14)$ when restricted to pregnancies with laboratory-confirmed ZIKV infection and 15\% $(95 \% \mathrm{Cl}=8 \%-26 \%)$ of fetuses/infants of completed pregnancies with confirmed ZIKV infection in the first trimester (17). Both symptomatic and asymptomatic infections during pregnancy seem to result in similar percentages of birth defects $(17,18)$.

Prior to 2015, only one laboratory-confirmed case of ZIKV infection had ever been reported in Canada-in a traveller returning from Thailand (20). In December 2015, Canada reported its first travel-associated case linked to the outbreak in the Americas (21). To date, no local transmission has been reported, as the primary mosquito vectors-Aedes aegypti and Aedes albopictus - are not established here. Although local transmission via mosquitoes in Canada is unlikely, Canadians make an estimated 7.3 million visits to the Caribbean, Central and South America and Mexico annually and also travel in significant numbers to the Asia-Pacific and African regions where ZIKV continues to circulate (22). As of June 29, 2017, there were 56 countries or areas reporting new introduction or re-introduction of ZIKV since 2015 and an additional 20 that reported ZIKV prior to 2015 with ongoing transmission (23). A number of countries are reporting a downward trend in cases; however, there are still some countries experiencing increases (24). The persistence and recirculation of ZIKV as immunity builds and wanes in affected populations, along with seasonal changes in vector activity, is largely unknown and is of ongoing concern (25). The Government of Canada has responded to the spread of ZIKV by issuing a travel health notice with recommendations for pregnant women and those planning a pregnancy to avoid travel to countries with ongoing ZIKV outbreaks (26). In addition, Canadian Recommendations on Prevention and Treatment of Zika virus were developed by Canada's Committee to Advise on Tropical Medicine and Travel (CATMAT) to inform Canadian health care practitioners on the health risks related to ZIKV and recommendations on how to mitigate these risks (27).

Following the declaration of a PHEIC by the WHO, Canadian federal, provincial and territorial partners agreed to national reporting of ZIKV cases on a temporary basis to:

- Fulfill International Health Regulation (IHR) reporting requests

- Maintain situational awareness of the context in Canada, including the assessment of where Canadians are being infected and the likely mode of transmission

- Assess and inform the level of risk to the Canadian public where possible

- Contribute to the international body of knowledge on ZIKV

This article describes the epidemiology of travel-related ZIKV cases in Canada from October 2015 to June 2017 and reviews them in the context of the international outbreak in the Americas.

\section{Methods}

\section{Laboratory diagnosis}

Confirmation of ZIKV infections is primarily carried out by two testing methodologies: polymerase chain reaction (PCR) detection of viral RNA in serum and/or urine samples and the serological identification of ZIKV specific antibodies in serum (27-29). Acute samples of serum and urine (collected within two weeks of symptom onset) are the most appropriate specimens for PCR testing since viremia is quite transient and the virus is usually present for only a brief period of time in these samples. Enzyme-linked immunosorbent assay (ELISA) is the primary serological screening test to identify possible exposures or cases of infection through the detection of viral lgM and IgG antibodies. However, due to cross reactivity with other related viruses, such as dengue, a plaque reduction neutralization assay must also be performed to identify ZIKV-specific antibodies in samples that are positive by ELISA procedures. Antibodies to ZIKV usually develop within three to four weeks after exposure and can be detected for several months (lgM) or years (neutralizing lgG). In certain cases, individuals may have been previously exposed to other flaviviruses through mosquito bites or vaccination (e.g., yellow fever, Japanese encephalitis virus vaccines), which can lead to further complications when interpreting serological results. Significant serum neutralization titres to both dengue and ZIKV may be identified in samples from certain individuals (e.g., secondary flavivirus infections), which result in the documentation of these cases as "flavivirus exposures" with no definitive identification of the infecting virus.

Initially, all laboratory testing was conducted at the National Microbiology Laboratory (NML); however, public health laboratories in British Columbia, Alberta, Ontario and Quebec have adopted PCR testing in their respective jurisdictions. Testing efforts focus primarily on pregnant women and symptomatic travellers. Serological testing is currently performed at the NML; however, sensitive commercial IgM and IgG ELISAs are now available and will allow for some provincial laboratories to include screening assays as part of their diagnostic capability.

\section{Epidemiology}

A case was defined as a resident of Canada with laboratory confirmation of ZIKV infection by one or more of the following, with or without clinical evidence: 1) isolation of virus from, or detection of specific viral antigen or nucleic acid from an 
appropriate clinical specimen; or 2) viral lgM antibodies against ZIKV in an appropriate clinical specimen and the identification of confirmatory virus-specific neutralizing antibodies in the same or a later specimen, or a demonstrated seroconversion or diagnostic rise (four-fold or greater change) in virus-specific neutralizing antibody titers in paired sera.

Cases of ZIKV infection were identified by provincial and territorial health authorities, and reported on a regular basis to the Public Health Agency of Canada (PHAC). Case information requested included date of illness onset, age category, sex, pregnancy status and location(s) and dates of travel.

The date of exposure for cases was estimated using the return travel date or onset of illness less seven days if return date was not available. Cases that travelled to multiple countries or those with neither dates available were not assigned an exposure date. Status of the outbreak in the country of travel was determined for each case by the epidemic curve for the country at the time of their exposure. The "outbreak period" or time period of "high activity" for each country was designated as the time from when cases first increased substantially (often tripled or more) from the initial number of reported cases, to the time when the number of cases returned to a level similar to the initial reported case numbers. The time before the first outbreak period was designated as "low activity" or "early in the outbreak". All other time periods, whether in between outbreak waves, or late in the outbreak, were considered "low activity" time periods.

Estimates for the monthly number of Canadians travelling outside of Canada to other countries in the Americas were obtained from two sources: yearly counts of travellers to specific countries and regions were obtained from the International Travel Survey, Statistics Canada, 2015 (22); and monthly traveller counts for the Americas in 2015 and 2016 were obtained using passenger-level ticket sales data from the International Air Transport Association (IATA). The IATA data comprise the full route itineraries of travellers, including their initial airport of embarkation, final airport destination and, where applicable, connecting airports. These data account for an estimated $90 \%$ of all trips on commercial flights worldwide, while the remaining $10 \%$ are modelled using airline market intelligence. Numbers for 2017 were estimated using an average of the monthly values in 2015 and 2016.

Data to produce the epidemic curves of autochthonous cases for each region of the Americas were extracted from country-specific epidemic curves on the Pan American Health Organization (PAHO) website using the WebPlotDigitizer tool (24). The countries used in the estimates were as follows:

- North America: Mexico

- Caribbean: Anguilla, Antigua and Barbuda, Aruba, Barbados, Curaçao, Dominica, Dominican Republic, Bonaire, Saint Eustatius, Saba, Cayman Islands, Grenada, Guadeloupe, Haiti, Jamaica, Martinique, Montserrat, Puerto Rico, Saint Barthelemy, Saint Kitts and Nevis, Saint Martin, Saint Vincent and the Grenadines, Saint Maarten, U.S. Virgin Islands, St. Thomas, St. Croix, St. John, Trinidad and Tobago, Turks and Caicos

- Central America: Belize, Costa Rica, El Salvador, Guatemala, Honduras, Nicaragua, Panama
- South America: Argentina, Bolivia, Brazil, Colombia, Ecuador, French Guyana, Guyana, Paraguay, Peru, Suriname and Venezuela

\section{Results}

Between May 2015 and June 7, 2017, over 22,000 samples were tested by the National Microbiology Laboratory. The number of samples received each week increased dramatically around week six (February 7-13, 2016). Since that time, testing levels have remained high with an average of 320 samples being submitted on a weekly basis (Range: 165-500 samples weekly), despite the number of positive samples decreasing (Figure 1).

\section{Figure 1: Number and percentage of Zika positive patients tested by the National Microbiology Laboratory, Canada, January 2015-June 2017 ${ }^{a}$}

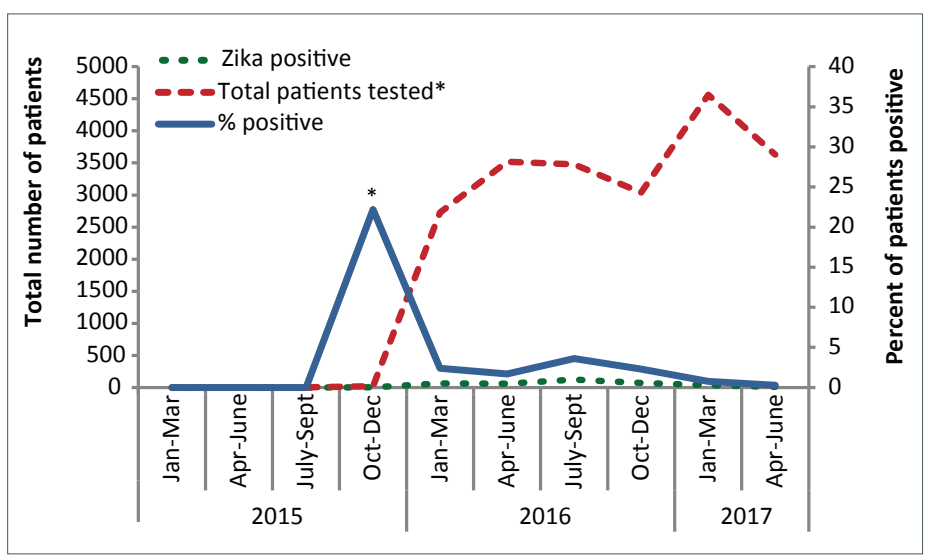

${ }^{a}$ From October to December 2015, 18 samples were tested; of those four (22\%) were positive

As of June 7, 2017, there have been 513 confirmed cases of ZIKV across all 10 provinces. Information on transmission mode was available for 512 cases and, of these, 507 (99\%) acquired ZIKV infection while travelling to affected regions. An additional three cases with no history of travel were infected through sexual contact with an infected traveller. Two $(n=2)$ cases of maternal-fetal transmission were reported. Fifty-five percent (55\%) of cases were between the age of $20-44$ years, and $64 \%$ were female (Table 1).

Table 1: Confirmed cases by age category and sex, Canada, October 2015-June 2017

\begin{tabular}{|l|r|r|r|r|}
\hline \multicolumn{1}{|c|}{$\begin{array}{c}\text { Age } \\
\text { (years) }\end{array}$} & Female & Male & Unknown & $\begin{array}{c}\text { Total (\% of } \\
\text { Total) }\end{array}$ \\
\hline Newborn-1 & 2 & 0 & 0 & $2(<1 \%)$ \\
\hline $1-19$ & 13 & 9 & 0 & $22(4 \%)$ \\
\hline $20-44$ & 195 & 86 & 0 & $281(55 \%)$ \\
\hline $45-64$ & 96 & 69 & 6 & $171(33 \%)$ \\
\hline$>64$ & 20 & 17 & 0 & $37(7 \%)$ \\
\hline $\begin{array}{l}\text { Total }(\% \text { of } \\
\text { Total) }\end{array}$ & $326(64 \%)$ & $181(35 \%)$ & $6(1 \%)$ & $513(100 \%)$ \\
\hline
\end{tabular}


Of those with information available $(n=499), 99 \%(n=492)$ reported symptoms prior to testing. Dates of illness onset ranged from October 12, 2015-March 30, 2017, with a peak noted in July and August 2016 (Figure 2). There were 35 pregnancies reported among Zika-infected women; however pregnancy outcomes were not collected routinely so only limited data were available. Of the four reported pregnancy outcomes, two of the infants had no apparent anomalies at birth and two of the fetuses/infants had Zika-related anomalies.

Figure 2: Number of confirmed travel-associated Zika virus cases by month of symptom onset and region of travel, Canada, October 2015-June $2017(n=334)^{a}$

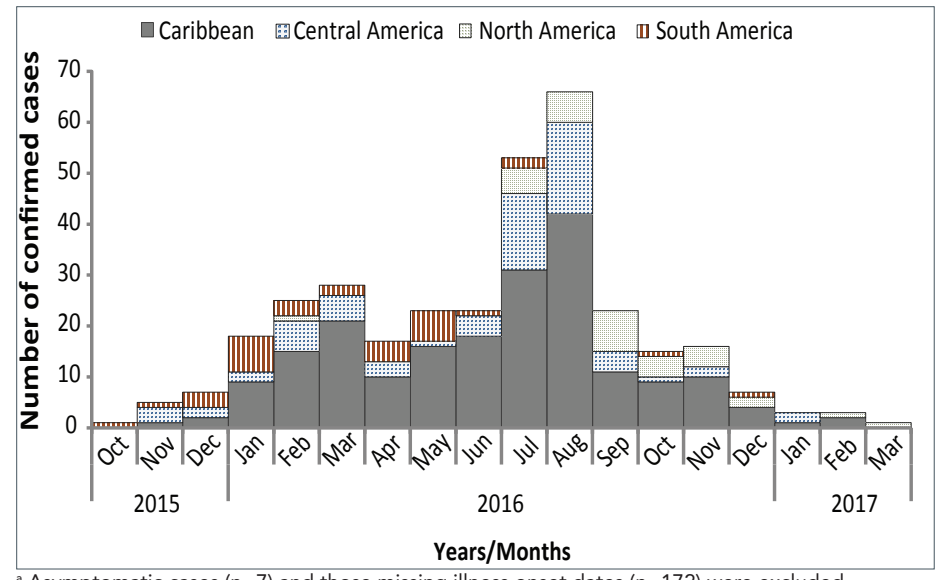

Overall, $66 \%$ of Canadian travellers were infected while visiting the Caribbean, $19 \%$ in Central America, $10 \%$ in North America (Mexico) and 6\% in South America (Appendix 1).

Most (83\%) of the cases travelled to their destination countries when the country was reporting high numbers of cases (i.e., during the "outbreak" period); however, there were a few cases who travelled to countries before those countries reported their first case $(2 \%)$, or in periods of lower activity (16\%) (Table 2).

Table 2: Timing of travel in relation to Zika virus outbreak status in country of travel: Canada, 2015-2017

\begin{tabular}{|l|r|r|}
\hline \multicolumn{1}{|c|}{$\begin{array}{c}\text { Status of outbreak in country of } \\
\text { travel }\end{array}$} & $\begin{array}{r}\text { Number } \\
\text { of cases }\end{array}$ & \multicolumn{1}{|c|}{$\begin{array}{c}\text { \% of } \\
\text { total } \\
\text { cases }\end{array}$} \\
\hline Prior to notification of first case & 5 & 2 \\
\hline Low activity: early in the outbreak & 16 & 6 \\
\hline $\begin{array}{l}\text { High activity: during the main outbreak } \\
\text { period }\end{array}$ & 240 & 83 \\
\hline $\begin{array}{l}\text { Low activity: late in the outbreak or in } \\
\text { between outbreak waves }\end{array}$ & 28 & 10 \\
\hline Total & 289 & 100 \\
\hline
\end{tabular}

The pattern of travel-associated cases observed, by region, appears to more closely coincide with Zika transmission activity in the region, rather than number of individuals travelling from Canada (Figure 3).
Figure 3: Monthly travel patterns and Canadian Zika virus cases by region of travel
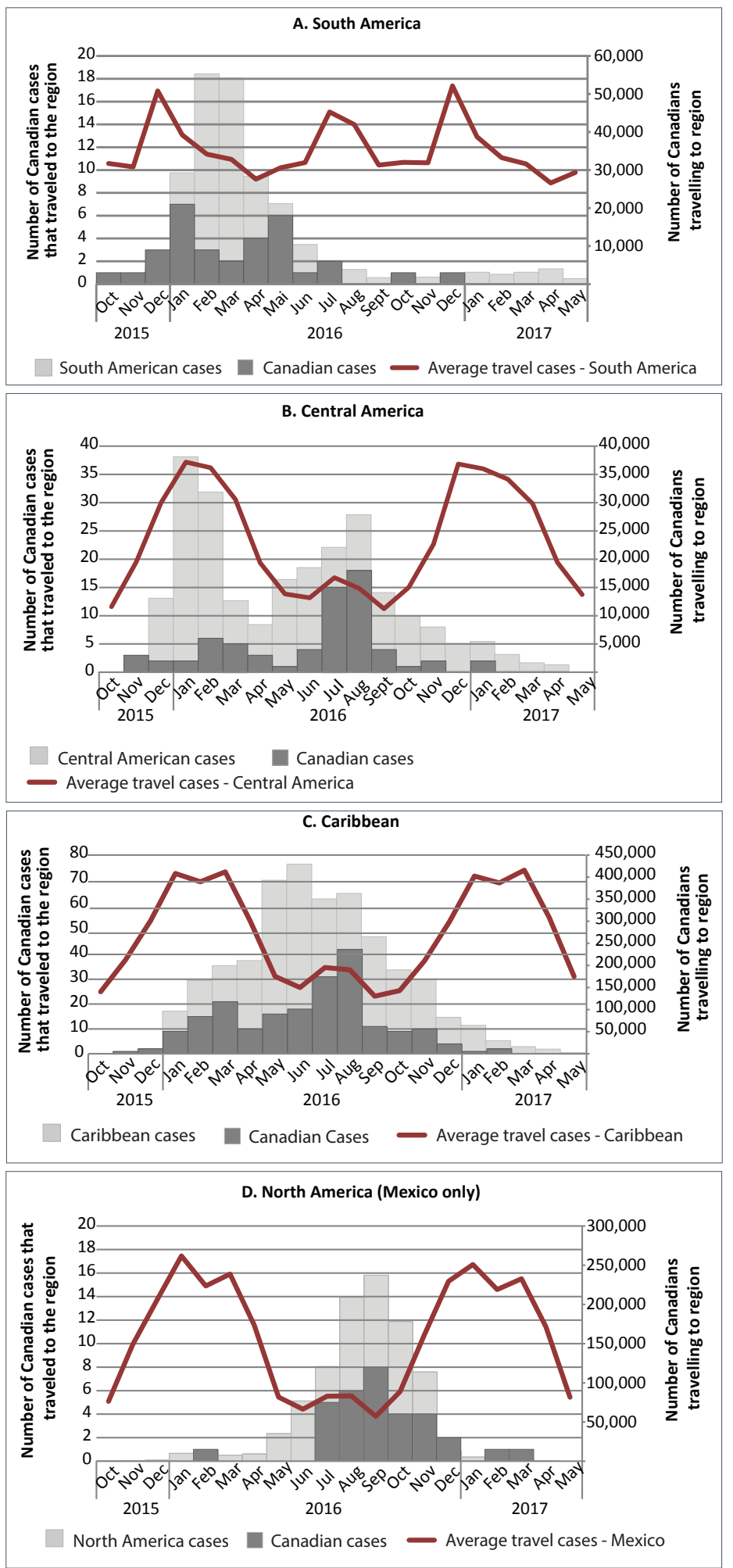

Note: Travel patterns (red line) and Canadian cases (dark grey bars) by region of travel, with pattern of endemic cases in region (light grey bars). Left vertical axis represent number of Canadian cases, right vertical axis represents the estimated number of individuals travelling from Canada to the region based on IATA monthly traveller data. For the estimated endemic cases per region, the pattern from the regional epidemic curve is shown, with no scaling 


\section{Discussion}

From October 2015 to June 2017, there were 507 confirmed cases of travel-related ZIKV and three cases of sexual transmission in Canada. Sixty-four percent of cases were female and, of those, $11 \%$ were pregnant. Finding a higher proportion of infected women than men is consistent with other international reports and likely reflects a testing and reporting bias rather than biological differences in susceptibility or exposure (30). Outcome information was available for only four pregnancies; two fetuses/infants had Zika-related anomalies while two did not have any apparent anomalies.

Despite the decline in number of cases in the past few months in returning travellers, the volume of laboratory testing remains high, reflecting the ongoing level of concern amongst pregnant couples and those planning pregnancies. There continues to be a significant number of pregnant 'worried well'; those who travelled to an at-risk region, did not develop symptoms but were tested. Given that both symptomatic and asymptomatic infections seem to result in similar percentages of birth defects, the concern is understandable. As infection rates continue to decline, there is a very low pre-test probability when testing asymptomatic individuals, which limits the value of testing. As a result, testing guidelines do not routinely recommend testing of asymptomatic pregnant women with no ongoing risk (i.e., travellers) (31). Several testing procedures for case identification are available; however, antibody cross reactivity between ZIKV and related viruses such as dengue can complicate diagnosis when using serological platforms. As well, individuals who have previously been exposed to related flaviviruses may exhibit serological responses that confound test interpretation. As a result some ZIKV exposures cannot be confirmed by immunoassays and are documented as "flavivirus infections". In these cases, physicians should be aware that a ZIKV exposure may still have occurred.

Almost all cases in Canada were travel-associated, and there is no evidence of autochthonous (local) transmission to date. Data suggests that sexual transmission alone is not likely to independently sustain an outbreak (30), and ongoing transmission is unlikely in the absence of tropical/subtropical Aedes spp. (32). The primary mosquito vectors-Aedes aegypti and Aedes albopictus - are not established in Canada and current research suggests that Canadian mosquito species are not competent hosts. Further, the risk of autochthonous transmission via the establishment of Aedes albopictus, given current climatic conditions, is predicted to be very low.

Illness in Canadian travellers generally coincided with outbreak intensity in the country of exposure rather than travel volume. It has been previously reported that the risk to travellers varies with the force of transmission cycles in the countries they are visiting, and that travellers as a group are not highly protected from infection in affected countries by virtue of their traveller status (32). The peak in cases recorded in July and August of 2016 was due to increases in cases exposed in Central America and the Caribbean, and to some extent from Mexico, but at a time when travel to these destinations are typically at their seasonal lows. Climatic factors such as temperature, humidity and precipitation have been shown to affect vector abundance, and ultimately level of disease transmission for diseases such dengue and chikungunya (33), resulting in seasonal trends in transmission favouring the warmer, wetter months. Both outbreak intensity and seasonality of ZIKV transmission should be monitored over time in order to inform the timing of public health education campaigns, as some may turn out be more effective in the 'off-peak' travel season when, despite lower absolute travel volumes, the risk of disease transmission may be higher.

\section{Limitations}

There are several limitations worth noting when interpreting the results. The laboratory testing results presented here only account for a subset of the testing done in Canada. Although NML initially conducted all ZIKV testing, as the outbreak progressed, three provinces adopted PCR testing for ZIKV in their respective jurisdictions. Findings reported here underestimate the total volume of ZIKV testing conducted in Canada.

Secondly, illness onset dates were not available for a number of cases, and were therefore excluded from the epidemic curve. To determine the impact of excluding these cases, a comparison was made between those with available information and those without. Estimated onset dates were generated for those missing onset dates using the PCR confirmation date, accounting for average testing and reporting delays. Based on this analysis, there was some variability in the timing of the cases with missing onset dates; however, this timing coincided with the peaks of the epidemic curve. While excluding these cases resulted in a slight attenuation of the peaks, the general shape of the curve remained the same, and no other meaningful changes were noted.

Pregnancy outcomes were not collected routinely as part of national reporting; therefore the very small subset of cases reported here should be interpreted with caution. More reliable estimates of the impact of ZIKV on pregnancy can be found elsewhere in the international literature.

\section{Conclusion}

Since late 2015, there was a significant increase in travel-associated ZIKV cases in Canada. Given that ZIKV can present like other viral diseases, and that many people only experience mild symptoms or no symptoms at all, this is likely a significant underestimate of the total travel-associated cases returning to Canada as a result of this international outbreak in the Americas. Cases in Canada and internationally are now on the decline; however, it is likely that cases will continue to be reported. The impact of seasonality and population immunity on the persistence of the virus in the Americas, and more broadly, is unknown. It is important to continue monitoring outbreak intensity and seasonality of ZIKV transmission in endemic countries in order to inform the timing of public health education campaigns, as some may turn out be more effective in the 'off-peak' travel season when, despite lower absolute travel volumes, the risk of disease transmission may be higher.

Zika virus is the third example of a recent arbovirus emerging into the Western Hemisphere with significant impact on human health (West Nile virus, chikungunya). Ongoing national and international collaboration is needed to prepare for and respond to these emerging diseases. Further application of new diagnostic platforms such as commercial screening ELISAs will enhance and expand laboratory testing capacity in Canada.

The PHAC and CATMAT recommend that pregnant women and those planning a pregnancy should postpone travel to areas 
where ZIKV transmission is ongoing $(27,34)$. Patients with clinical symptoms consistent with ZIKV and pregnant women or couples planning pregnancies, who have recently returned from travelling to countries where the virus is circulating, should see their health care provider to discuss their situation and risk. Health care providers should continue to educate their patients about the risks for, and measures to prevent, ZIKV infection and other mosquito-borne infections.

\section{Authors' statement}

JT- Conceptualization, Methodology, Analysis, Interpretation, Writing original draft, review and editing

LV- Conceptualization, Methodology, Analysis, Interpretation, Writing original draft (parts) and review

MD- Conceptualization, Investigation, Interpretation, Writing original draft (parts) and review

HW- Investigation, Analysis, Writing - review

EP- Investigation, Writing original draft (parts) and review

SC- Investigation, Writing original draft and review

JG- Investigation, Conceptualization, Writing original draft (parts) and review

MG- Methodology, Analysis, Writing original draft (parts) and review

KK- Methodology, Analysis, Writing original draft (parts) and review

PAB- Conceptualization, Writing original draft, review and editing

\section{Conflict of interest}

None.

\section{Acknowledgements}

The authors wish to acknowledge the valuable contributions of our epidemiology and laboratory partners in the provinces and territories who collaborated in responding to the Zika virus outbreak in the Americas.

\section{References}

1. Dick GW. Zika virus. II. Pathogenicity and physical properties. Trans R Soc Trop Med Hyg 1952 Sep;46(5):521-34. DOI (http://dx.doi.org/10.1016/0035-9203(52)90043-6). PubMed (https://www.ncbi.nlm.nih.gov/entrez/query.fcgi?cmd=Retrie ve\&db=PubMed\&list_uids=12995441\&dopt=Abstract).

2. Dick GW, Kitchen SF, Haddow AJ. Zika virus. I. Isolations and serological specificity. Trans R Soc Trop Med Hyg 1952 Sep;46(5):509-20. DOI (http://dx.doi.org/10.1016/00359203(52)90042-4). PubMed (https://www.ncbi.nlm.nih. gov/entrez/query.fcgi?cmd=Retrieve\&db=PubMed\&lis t_uids=12995440\&dopt=Abstract).

3. Song BH, Yun SI, Woolley M, Lee YM. Zika virus: History, epidemiology, transmission, and clinical presentation. J Neuroimmunol 2017 Jul;308:50-64. DOl (http://dx.doi. org/10.1016/j.jneuroim.2017.03.001). PubMed (https://www.
ncbi.nlm.nih.gov/entrez/query.fcgi?cmd=Retrieve\&db=PubM ed\&list_uids=28285789\&dopt=Abstract).

4. Duffy MR, Chen TH, Hancock WT, Powers AM, Kool JL, Lanciotti RS et al. Zika virus outbreak on Yap Island, Federated States of Micronesia. N Engl J Med 2009 Jun;360(24):2536-43. DOI (http://dx.doi.org/10.1056/ NEJMoa0805715). PubMed (https://www.ncbi.nlm.nih. gov/entrez/query.fcgi?cmd=Retrieve \&db=PubMed\&lis t_uids=19516034\&dopt=Abstract).

5. Cao-Lormeau VM, Musso D. Emerging arboviruses in the Pacific. Lancet 2014 Nov;384(9954):1571-2. DOI (http:// dx.doi.org/10.1016/S0140-6736(14)61977-2). PubMed (https://www.ncbi.nlm.nih.gov/entrez/query.fcgi?cmd=Retrie ve\&db=PubMed\&list_uids=25443481\&dopt=Abstract).

6. Musso D, Nilles EJ, Cao-Lormeau VM. Rapid spread of emerging Zika virus in the Pacific area. Clin Microbiol Infect 2014 Oct;20(10):O595-6. DOI (http://dx.doi. org/10.1111/1469-0691.12707). PubMed (https://www.ncbi. $\mathrm{nlm}$.nih.gov/entrez/query.fcgi?cmd=Retrieve \&db=PubMed\&l ist_uids=24909208\&dopt=Abstract).

7. World Health Organization. WHO statement on the first meeting of the International Health Regulations (2005) (IHR 2005) Emergency Committee on Zika virus and observed increase in neurological disorders and neonatal malformations. 2016. WHO: 2016. http://www.who.int/ mediacentre/news/statements/2016/1st-emergencycommittee-zika/en/. [Accessed June 5, 2017].

8. Besnard M, Lastere S, Teissier A, Cao-Lormeau V, Musso D. Evidence of perinatal transmission of Zika virus, French Polynesia, December 2013 and February 2014. Euro Surveill 2014 Apr;19(13). DOI (http://dx.doi.org/10.2807/1560-7917. ES2014.19.13.20751). PubMed (https://www.ncbi.nlm.nih. gov/entrez/query.fcgi?cmd=Retrieve $\& \mathrm{db}=$ PubMed\&lis t_uids=24721538\&dopt=Abstract).

9. Oliveira Melo AS, Malinger G, Ximenes R, Szejnfeld PO, Alves Sampaio S, Bispo de Filippis AM. Zika virus intrauterine infection causes fetal brain abnormality and microcephaly: tip of the iceberg? Ultrasound Obstet Gynecol 2016 Jan;47(1):67. DOI (http://dx.doi.org/10.1002/uog.158310). PubMed (https://www.ncbi.nlm.nih.gov/entrez/query.fcgi?cmd=Retrie ve\&db=PubMed\&list_uids=26731034\&dopt=Abstract).

10. Atkinson B, Thorburn F, Petridou C, Bailey D, Hewson R, Simpson AJ et al. Presence and Persistence of Zika Virus RNA in Semen, United Kingdom, 2016. Emerg Infect Dis 2017 Apr;23(4):611-5. DOI (http://dx.doi.org/10.3201/ eid2304.161692). PubMed (https://www.ncbi.nlm.nih. gov/entrez/query.fcgi?cmd=Retrieve\&db=PubMed\&lis t_uids=27997333\&dopt=Abstract).

11. Musso D, Roche C, Robin E, Nhan T, Teissier A, CaoLormeau VM. Potential sexual transmission of Zika virus. Emerg Infect Dis 2015 Feb;21(2):359-61. DOI (http://dx.doi. org/10.3201/eid2102.141363). PubMed (https://www.ncbi. $\mathrm{nlm}$.nih.gov/entrez/query.fcgi?cmd=Retrieve \&db=PubMed\&l ist_uids=25625872\&dopt=Abstract).

12. Musso D, Nhan T, Robin E, Roche C, Bierlaire D, Zisou K et al. Potential for Zika virus transmission through blood transfusion demonstrated during an outbreak in French ynesia, November 2013 to February 2014. Euro Surveill 2014 Apr;19(14). DOI (http://dx.doi.org/10.2807/1560-7917. 
ES2014.19.14.20761). PubMed (https://www.ncbi.nlm.nih. gov/entrez/query.fcgi?cmd=Retrieve $\& \mathrm{db}=$ PubMed\&lis t_uids=24739982\&dopt=Abstract).

13. Herriman R. Transfusion-associated Zika virus reported in Brazil. Outbreak News Today. December 18, 2015. http:// outbreaknewstoday.com/transfusion-associated-zika-virusreported-in-brazil-76935/. [Accessed June 12, 2017].

14. Centers for Disease Control and Prevention. Zika virus. CDC 24/7;2017. https://www.cdc.gov/zika/transmission/index. html. [Accessed June 13, 2017].

15. Krow-Lucal ER, Biggerstaff BJ, Staples JE. Estimated Incubation Period for Zika Virus Disease. Emerg Infect Dis 2017 May;23(5):841-5. DOl (http://dx.doi.org/10.3201/ eid2305.161715). PubMed (https://www.ncbi.nlm.nih. gov/entrez/query.fcgi?cmd=Retrieve\&db=PubMed\&lis t_uids=28277198\&dopt=Abstract).

16. World Health Organization. Situation Report: Zika Virus Microcephaly Guillain Barre Syndrome. WHO: 10 March 2017. http://apps.who.int/iris/bitstream/10665/254714/1/ zikasitrep10Mar17-eng.pdf?ua=1. [Accessed June 12, 2017].

17. Reynolds MR, Jones AM, Petersen EE, Lee EH, Rice ME, Bingham A et al.; U.S. Zika Pregnancy Registry Collaboration. Vital Signs: Update on Zika Virus-Associated Birth Defects and Evaluation of All U.S. Infants with Congenital Zika Virus Exposure - U.S. Zika Pregnancy Registry, 2016. MMWR Morb Mortal Wkly Rep 2017 Apr;66(13):366-73. DOI (http://dx.doi. org/10.15585/mmwr.mm6613e1). PubMed (https://www. ncbi.nlm.nih.gov/entrez/query.fcgi?cmd=Retrieve\&db=PubM ed\&list_uids=28384133\&dopt=Abstract).

18. Shapiro-Mendoza CK, Rice ME, Galang RR, Fulton AC, VanMaldeghem K, Prado MV et al.; Zika Pregnancy and Infant Registries Working Group. Pregnancy Outcomes After Maternal Zika Virus Infection During Pregnancy - U.S. Territories, January 1, 2016-April 25, 2017. MMWR Morb Mortal Wkly Rep 2017 Jun;66(23):615-21. DOI (http://dx.doi. org/10.15585/mmwr.mm6623e1). PubMed (https://www. ncbi.nlm.nih.gov/entrez/query.fcgi?cmd=Retrieve\&db=PubM ed\&list_uids=28617773\&dopt=Abstract).

19. Duarte G, Moron AF, Timerman A, Fernandes CE, Mariani Neto C, Almeida Filho GL et al. Zika Virus Infection in Pregnant Women and Microcephaly. Rev Bras Ginecol Obstet 2017 May;39(5):235-48. DOI (http://dx.doi. org/10.1055/s-0037-1603450). PubMed (https://www.ncbi. $\mathrm{nlm}$.nih.gov/entrez/query.fcgi?cmd=Retrieve \&db=PubMed\&l ist_uids=28575919\&dopt=Abstract).

20. Fonseca K, Meatherall B, Zarra D, Drebot M, MacDonald $\mathrm{J}$, Pabbaraju $\mathrm{K}$ et al. First case of Zika virus infection in a returning Canadian traveler. Am J Trop Med Hyg 2014 Nov;91(5):1035-8. DOI (http://dx.doi.org/10.4269/ ajtmh.14-0151) PubMed (https://www.ncbi.nlm.nih.gov/ entrez/query.fcgi?cmd=Retrieve \&db=PubMed\&list_ uids $=25294619 \&$ dopt $=$ Abstract)

21. Teale A, Payne M, England J, Morshed M, Hull M. Zika virus, an emerging flavivirus, as a cause of fever and rash in a traveller returning from Central America. Can Commun Dis Rep 2016;42(3):68-71. http://www.phac-aspc.gc.ca/publicat/ ccdr-rmtc/16vol42/dr-rm42-3/assets/pdf/16vol42_3-ar-04eng.pdf
22. Statistics Canada. International Travel Survey: Electronic questionnaires and Air Exit Survey (ITS). Ottawa (ON); Statstics Canada: 2015. http://www23.statcan.gc.ca/imdb/ p2SV.pl?Function=getSurvey\&SDDS=3152. [Accessed July 14, 2017].

23. World Health Organization. Zika virus (ZIKV) classification table: Data as of 20 June 2017. WHO: 2017. http://apps. who.int/iris/bitstream/10665/255767/1/zika-classification20June17-eng.pdf?ua=1. [Accessed July 28, 2017].

24. Pan American Health Organization. Web Plot Digitizer. [Online].; 2017. https://automeris.io/WebPlotDigitizer/. [Accessed July 6, 2017].

25. Baud D, Gubler DJ, Schaub B, Lanteri MC, Musso D. An update on Zika virus infection. Lancet 2017 Nov;390(10107):2099-109. DOl (http://dx.doi.org/10.1016/ S0140-6736(17)31450-2) PubMed (https://www.ncbi.nlm. nih.gov/entrez/query.fcgi?cmd=Retrieve $\& d b=$ PubMed\&li st_uids=28647173\&dopt=Abstract).

26. Government of Canada. Zika virus: Advice for travellers. 2017. https://travel.gc.ca/travelling/health-safety/travelhealth-notices/152

27. Zika Working Group; Committee to Advise on Tropical Medicine and Travel (CATMAT). Canadian recommendations on the prevention and treatment of Zika virus: update. Can Commun Dis Rep 2016;42(5):101-11. Available from: https://www.canada.ca/en/public-health/services/reportspublications/canada-communicable-disease-report-ccdr/ monthly-issue/2016-42/ccdr-volume-42-5-may-5-2016/ccdrvolume-42-5-may-5-2016-zika-virus.html\#a7

28. Government of Canada. Recommendations on the Prevention and Treatment of Zika Virus for Canadian health care professionals. 2017. http://healthycanadians.gc.ca/ publications/diseases-conditions-maladies-affections/ committee-statement-treatment-prevention-zika-declarationcomite-traitement-prevention/index-eng.php?_ga=1.154058 232.1718591151.1469533975

29. Government of Canada. For health professionals: Zika virus. 2017. https://www.canada.ca/en/public-health/services/ diseases/zika-virus/health-professionals-zika-virus.html

30. Maxian O, Neufeld A, Talus EJ, Childs LM, Blackwood JC. Zika virus dynamics: When does sexual transmission matter? Epidemics. 2017 Jun; pii: S1755-4365(17)30109-3. DOI (https://doi.org/10.1016/j.epidem.2017.06.003). PubMed (https://www.ncbi.nlm.nih.gov/pubmed/28688996).

31. Oduyebo T, Polen KD, Walke HT, Reagan-Steiner $S$, Lathrop E, Rabe IB et al. Update: Interim Guidance for Health Care Providers Caring for Pregnant Women with Possible Zika Virus Exposure - United States (Including U.S. Territories), July 2017. MMWR Morb Mortal Wkly Rep 2017 Jul;66(29):781-93. DOI (http://dx.doi.org/10.15585/ mmwr.mm6629e1). PubMed (https://www.ncbi.nlm.nih. gov/entrez/query.fcgi?cmd=Retrieve\&db=PubMed\&lis t_uids=28749921\&dopt=Abstract).

32. Ogden NH, Fazil A, Safronetz D, Drebot MA, Wallace J, Rees EE et al. Risk of travel-related cases of Zika virus infection is predicted by transmission intensity in outbreak-affected countries. Parasit Vectors 2017 Jan;10(1):41. DOI (http:// dx.doi.org/10.1186/s13071-017-1977-z). PubMed (https:// 
www.ncbi.nlm.nih.gov/entrez/query.fcgi?cmd=Retrieve \&db= PubMed\&list_uids=28122631\&dopt=Abstract).

33. da Cruz Ferreira DA, Degener CM, de Almeida MarquesToledo C, Bendati MM, Fetzer LO, Teixeira CP et al. Meteorological variables and mosquito monitoring are good predictors for infestation trends of Aedes aegypti, the vector of dengue, chikungunya and Zika. Parasit Vectors 2017 Feb;10(1):78. DOI (http://dx.doi.org/10.1186/ s13071-017-2025-8). PubMed (https://www.ncbi.nlm.nih.
gov/entrez/query.fcgi?cmd=Retrieve \&db=PubMed\&lis t_uids=28193291\&dopt=Abstract).

34. Public Health Agency of Canada. Zika virus. Ottawa (ON); PHAC: 2017. https://www.canada.ca/en/public-health/ services/diseases/zika-virus.html 
Appendix 1: Zika infection in Canadian travellers, by region and country of travel, May 2015 - June $2017\left(\mathrm{~N}=493^{\mathrm{a}}\right)$

\begin{tabular}{|c|c|c|c|c|c|c|c|c|}
\hline Region & $\begin{array}{c}\text { Country/area of } \\
\text { travel }\end{array}$ & $\mathrm{n}$ & $\begin{array}{l}\text { Estimated Canadian } \\
\text { travellers (May } \\
\text { 2015-June 2017) }\end{array}$ & $\begin{array}{c}\text { Estimated } \\
\text { infection rate } \\
\text { (per } 100,000 \\
\text { travellers) }\end{array}$ & $\begin{array}{l}\text { Total \# } \\
\text { of travel } \\
\text { cases per } \\
\text { region }\end{array}$ & $\begin{array}{l}\text { Percent } \\
\text { of travel } \\
\text { cases per } \\
\text { region }\end{array}$ & $\begin{array}{l}\text { Estimated } \\
\quad \text { total } \\
\text { travellers } \\
\text { to region }\end{array}$ & $\begin{array}{l}\text { Estimated infection } \\
\text { rate per } 100,000 \\
\text { travellers to region }\end{array}$ \\
\hline \multirow{17}{*}{ Caribbean } & $\begin{array}{l}\text { Antigua and } \\
\text { Barbuda }\end{array}$ & 4 & 102,917 & 3.89 & \multirow{17}{*}{322} & \multirow{17}{*}{65.71} & \multirow{17}{*}{$2,897,083$} & \multirow{17}{*}{1.11} \\
\hline & Bahamas & 3 & 454,583 & 0.66 & & & & \\
\hline & Barbados & 53 & 394,375 & 13.44 & & & & \\
\hline & $\begin{array}{l}\text { Bonaire, Saint } \\
\text { Eustatius and Saba }\end{array}$ & 4 & - & - & & & & \\
\hline & $\begin{array}{l}\text { British Virgin } \\
\text { Islands }\end{array}$ & 4 & 52,083 & 7.68 & & & & \\
\hline & $\begin{array}{l}\text { Caribbean } \\
\text { (unspecified) }\end{array}$ & 12 & - & - & & & & \\
\hline & Curacao & 15 & - & - & & & & \\
\hline & $\begin{array}{l}\text { Dominican } \\
\text { Republic }\end{array}$ & 40 & $1,014,167$ & 3.94 & & & & \\
\hline & Grenada & 10 & 25,208 & 39.67 & & & & \\
\hline & Guadeloupe & 5 & 46,042 & 10.86 & & & & \\
\hline & Haiti & 19 & 82,500 & - & & & & \\
\hline & Jamaica & 78 & 461,042 & 16.92 & & & & \\
\hline & Martinique & 7 & 9,792 & 71.49 & & & & \\
\hline & Saint Lucia & 8 & 88,958 & 8.99 & & & & \\
\hline & $\begin{array}{l}\text { Saint Martin/ } \\
\text { Saint Maarten }\end{array}$ & 17 & 17,292 & 98.31 & & & & \\
\hline & $\begin{array}{l}\text { Saint Vincent and } \\
\text { the Grenadines }\end{array}$ & 8 & 17,708 & 45.18 & & & & \\
\hline & $\begin{array}{l}\text { Trinidad and } \\
\text { Tobago }\end{array}$ & 35 & 130,417 & 26.84 & & & & \\
\hline $\begin{array}{l}\text { North } \\
\text { America }\end{array}$ & Mexico & 47 & $4,012,292$ & 1.17 & 47 & 9.59 & $4,012,292$ & 1.17 \\
\hline \multirow{7}{*}{$\begin{array}{l}\text { Central } \\
\text { America } \\
\text { (unspecified) }\end{array}$} & Central America & 8 & - & - & \multirow{7}{*}{76} & \multirow{7}{*}{15.51} & \multirow{7}{*}{780,000} & \multirow{7}{*}{9.74} \\
\hline & Costa Rica & 15 & 362,708 & 4.14 & & & & \\
\hline & El Salvador & 9 & 85,208 & 10.56 & & & & \\
\hline & Guatemala & 10 & 58,333 & 17.14 & & & & \\
\hline & Honduras & 4 & 138,750 & 2.88 & & & & \\
\hline & Nicaragua & 29 & 62,083 & 46.71 & & & & \\
\hline & Panama & 1 & 72,917 & 1.37 & & & & \\
\hline \multirow{7}{*}{$\begin{array}{l}\text { South } \\
\text { America }\end{array}$} & Belize & 1 & 198125 & 0.50 & \multirow{7}{*}{45} & \multirow{7}{*}{9.18} & \multirow{7}{*}{$1,082,798$} & \multirow{7}{*}{4.16} \\
\hline & Brazil & 4 & 203333 & 1.97 & & & & \\
\hline & Colombia & 17 & 187,083 & 9.09 & & & & \\
\hline & Ecuador & 3 & 71,250 & 4.21 & & & & \\
\hline & Guyana & 14 & 135,000 & 10.37 & & & & \\
\hline & Peru & 1 & 274,792 & 0.36 & & & & \\
\hline & Venezuela & 5 & 13,125 & 38.10 & & & & \\
\hline \multirow{3}{*}{ Other } & Philippines & 1 & - & - & \multirow{3}{*}{3} & & \multirow{3}{*}{-} & \multirow{3}{*}{ - } \\
\hline & Thailand & 1 & - & - & & & & \\
\hline & Vietnam & 1 & - & - & & & & \\
\hline \multicolumn{2}{|l|}{ TOTAL } & 493 & $\mathrm{n} / \mathrm{a}$ & $\mathrm{n} / \mathrm{a}$ & 493 & 100 & $8,772,083$ & 5.59 \\
\hline
\end{tabular}

Abbreviations: "-", data not available; N, number of cases; n/a, not applicable

a Cases who travelled to more than one region $(n=14)$ were excluded

b Data source: International Travel Survey-Statistics Canada, 2015 data was adjusted to reflect estimated numbers over 25 months (May 1, 2015-June 1, 2017) (22) 